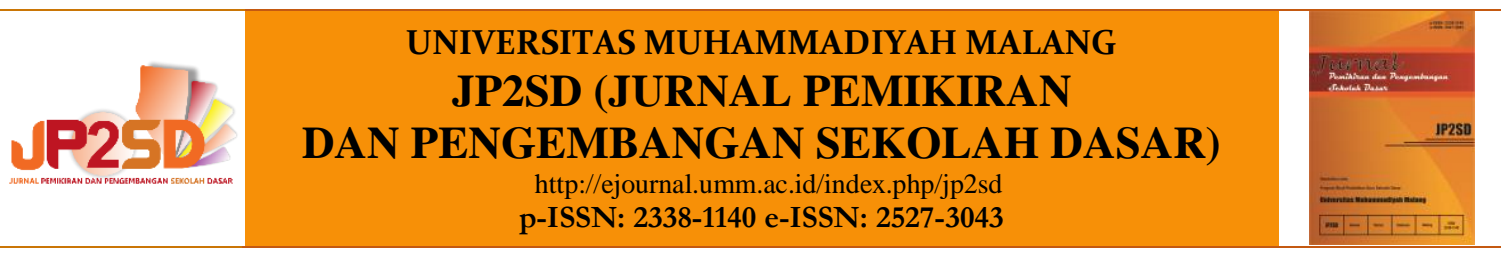

\title{
Hubungan Antara Body Mass Index dengan Physical Fitness Pada Mahasiswa PGSD
}

\author{
Abdurrohman Muzakki ${ }^{\text {a1 }}$, Setiya Yunus Saputra ${ }^{\text {b2 }}$ \\ ${ }^{a}$ Pendidikan Guru Sekolah Dasar, Universitas Muhammadiyah Malang, Indonesia \\ ${ }^{\mathrm{b}}$ Pendidikan Guru Sekolah Dasar, Universitas Muhammadiyah Malang, Indonesia \\ 1muzakki@umm.ac.id, ${ }^{2}$ setiyayunus@umm.ac.id
}

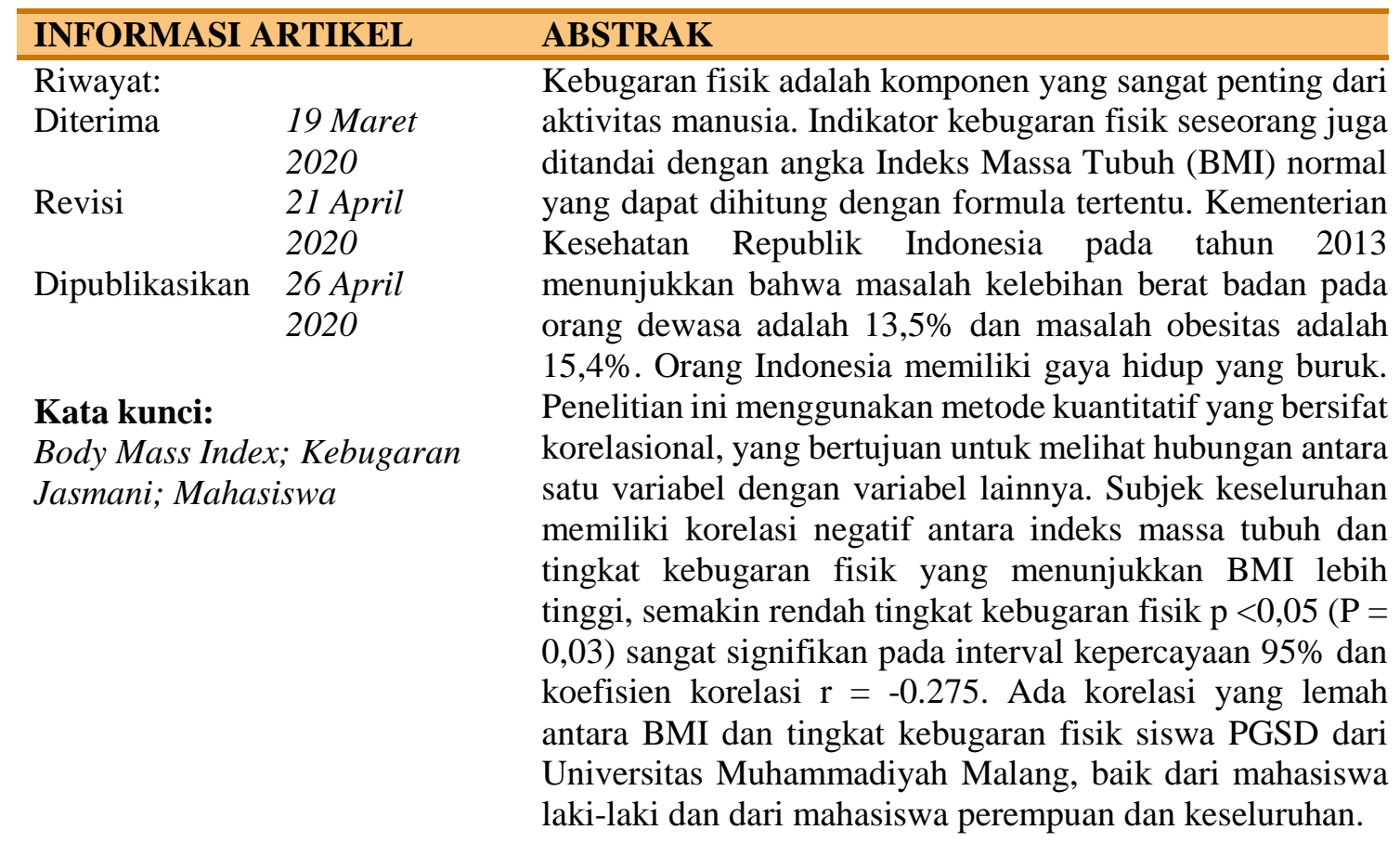

\section{ABSTRACT}

Keywords:

Body Mass Index; Physical

Fitness; Student

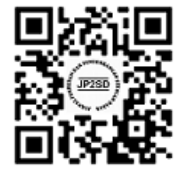

Copyright $@ 2020$,

Abdurrohman Muzakki, Setiya Yunus Saputra
Physical fitness is a very important component of human activity Indicators of one's physical fitness are also marked by the normal Body Mass Index (BMI) number which can be calculated with a certain formula. The Ministry of Health of the Republic of Indonesia in 2013 showed that the problem of overweight in adults was $13.5 \%$ and the problem of obesity was $15.4 \%$. Indonesian people have a bad lifestyle. This study uses a quantitative method that is correlational, which aims to see the relationship between one variable with another variable. The overall subject has a negative correlation between body mass index and physical fitness level which shows the higher BMI, the lower the level of physical fitness $\mathrm{p}<0.05(\mathrm{P}=0.03)$ is very significant at $95 \%$ confidence intervals and the correlation coefficient $r$ 
This is an open access article under the CC-BY-SA license
$=-0.275$. There is a weak correlation between BMI and physical fitness level of PGSD students of the University of Muhammadiyah Malang, both from male subjects and from female and overall subjects.

How to cite: Abdurrohman Muzakki, Setiya Yunus Saputra. (2020). Hubungan Antara Body

Mass Index dengan Physical Fitness pada Mahasiswa PGSD. Jurnal Pemikiran dan

$\begin{array}{lllllll}\text { Pengembangan Sekolah Dasar, Vol } 8 \text { No } 1, & 85 . & \text { doi: }\end{array}$

https://doi.org/10.22219/jp2sd.v8i1.12414

\section{PENDAHULUAN}

Melakukan olahraga merupakan kegiatan yang sangat penting bagi kebugaran. Aktifitas olahraga merupaka kegitan yang sangat komplek, ada berbagai kegiatan dan aktifitas memiliki tujan yang berbeda-beda, dari tujuan tersebut akan muncul sebuah motivasi untuk mecapai tujuan yang di inginkan, apakah tujuan tersebut untuk mencapai kebugaran, menurunkan berat badan atau mencapai sebuah prestasi, untuk mencapai kegiatan tersebut menjadi maksimal maka kebugaran jasmani menjadi kunci yang penting untuk menjalankan aktifitas tersebut. Hartono, dkk (2013: 6) menyatakan bahwa kebugaran jasmani merupakan aspek penting dari domain psikomotorik yang bertumpu pada perkembangan kemampuan biologis organ tubuh. Sementara menurut Widiastuti, (2015: 13) kesegaran jasmani merupakan aspek fisik dari kesegaran yang menyeluruh, yang membuat seseorang sanggup untuk menjalankan hidup produktif tanpa mengalami kelelahan yang berlebih dan masih sanggup melakukan aktifitas fisik yang lain. Sehingga dapat diambil kesimpulan bahwa kebugaran jasmani merupakan kebutuhan yang sangat penting bagi kehidupan, Kebugaran jasmani merupakan aktifitas fisik yang sangat baik bagi perkembangan anak dan proses pertumbuhannya. Hal tersebut disebabkan tingkat kebugaran jasmani menentukan kemampuan aktivitas fisik sehari-hari. Kebugaran jasmani semakin tinggi semakin tinggi pula capaian aktifitas fisik yang didapat.

Kebugaran jasmani merupakan salah satu faktor pendukung yang sangat penting bagi seseorang agar dapat melakukan berbagai macam aktifitas fisik, melakukan aktifitas sehari-hari secara efektif dan efisien dalam waktu yang lama tanpa mengalami kelelahan yang berlebih. Tingkat kebugaran jasmani yang baik diharapkan dapat meningkatkan kualitas peserta didik. Pencapaian kebugaran jasmani tidak hanya dilakukan dalam aktifitas yang berada di ruang lingkup pendidikan formal saja, tetapi juga dapat dilakukan di luar sekolah Sadoso Sumosardjuno (1992: 15). Seperti yang tertera dalam kalimat bahwa kebugaran jasmani merupakan aspek terdekat yang menghubungkan antara aktivitas fisik dengan kesehatan (Prakoso, Saifuddin, dan Burstiando, 2014). Aktivitas fisik mayoritas anak-anak saat ini cenderung menurun, dikarenakan lebih banyak bermain di dalam rumah yang erat kaitannya dengan kemajuan teknologi daripada di luar rumah yang tentunya masih tradisional dan membutuhkan banyak gerak tubuh. Hal tersebut menimbulkan kecemasan orang tua terhadap aktivitas gerak yang dilakukan anaknya, dengan jangka panjang jika diteruskan akan menimbulkan dampak negatif. Kurangnya kecukupan gerak dapat membuat anak terkena berbagai penyakit kronis seperti halnya kanker (Nazzari et al., 2016).

Kebugaran jasmani ada bebrapa tingkatan yang dapat mempengaruhi kebugaran seseorang salah satunya adalah kebugaran kardiorespirasi. Daya tahan kardiorespirasi atau daya tahan paru jantung adalah kapasitas sistem jantung, paru, dan pembuluh darah untuk berfungsi saat melakukan aktivitas sehari-hari dalam jangka waktu yang cukup 
lama tanpa mengalami kelelahan yang berarti sehingga akan mendapatkan hasil secara optimal (Wahjoedi, 2000: 59).

Rusli Lutan (2002: 46). Menyatakan dalam pengertian kardiorespirasi adalah kemampuan sistem peredaran darah dan pernapasan untuk membagikan oksigen serta makanan ke otot-otot yang bekerja sesuai dengan kebutuhan untuk memulihkan tubuh dari efek bekerja dan latihan fisik. Indikator dari kebugaran jasmani seseorang juga ditandai dengan normalnya angka Body Mass Index (BMI) yang dapat dihitung dengan rumus tertentu. Menurut kamus Merriam-Webster, Body Mass Index (BMI) Tubuh adalah ukuran lemak tubuh menggunakan perbandingan berat tubuh dalam kilogram dengan kuadrat dan tinggi badan dalam meter. Permasalahan berat badan yang berlebih (overweight) serta kegemukan (Obesitas) merupakan permasalahan yang telah lama terjadi pada Negara Indonesia. Pernyataan tersebut didukung oleh data dari Global Nutrution Report yaitu sebanyak $10 \%$ penduduk dewasa pada Negara Indonesia telah mengalami kelebihan berat badan (Overweight) serta sebanyak 2\% mengalami obestas (WHO,2007). Begitu pula merujuk pada data dari Riskesdas Departemen Kesehatan Republik Indonesia tahun 2013 yang menunjukkan bahwa permasalahan berat badan berlebih pada orang dewasa sebesar $13.5 \%$ dan masalah obesitas sebesar $15.4 \%$. jika jumlah data permasalahan tersebut disatukan maka jumlah penduduk yang mengalami permasalahan berat badan adaah 28.9\% (kemenkes RI,2013). Dapat diartikan bahwa Negara Indonesia memiliki jumlah masyarakat dengan permasalahan tubuh yang cukup besar karena hampir dari sepertiga penduduknya mengalami kelebihan berat badan. Cost and time menjadi kunci keterlibatan anak dalam beraktivitas olahraga (Somerset \& Hoare, 2018).

Terdapat beberapa penelitian mengenai aktivitas fisik dan obesitas. Menurut penelitian yang dilakukan oleh Laguna et. al (2013) pada 487 anak berusia 9 tahun dan 274 remaja 15 tahun di Spanyol menunjukkan bahwa anak berusia 9 tahun yang mengalami obesitas memiliki aktivitas fisik yang kurang dibandingkan dengan anak yang berat badannya normal sedangkan remaja berusia 15 tahun yang mengalami obesitas dan normal tidak terdapat hubungan yang signifikan pada aktivitas fisiknya. Penelitian tersebut sejalan dengan penelitan yang dilakukan oleh (Rumajar, Rompas, \& Babakal, 2015) pada 30 anak yang berumur 3-5 tahun di TK Providensia Manado yang menunjukkan adanya hubungan yang sangat bermakna antara aktivitas fisik responden dengan kejadian obesitas. Namun hal ini tidak sesuai dengan penelitian yang dilakukan oleh (Sari, Ernalia, \& Bebasari, 2017) pada 279 siswa SMPN di Pekanbaru yang menemukan bahwa tidak ada hubungan yang signifikan antara aktivitas fisik dengan kejadian obesitas. Adapun menurut Ogden et al, (2015) pada tahun 2011 sampai dengan 2014 anak-anak yang berusia 6 sampai 11 tahun di Amerika Serikat lebih banyak yang mengalami obesitas yaitu 17,5\% dibandingkan dengan anak yang berusia 2 sampai 5 tahun yaitu sekitar $8,9 \%$. Kejadian obesitas tidak hanya menjadi masalah bagi negara yang berpenghasilan tinggi, namun juga obesitas kini meningkat di negara berpenghasilan rendah dan menengah contohnya di negara Afrika jumlah anak-anak yang mengalami obesitas meningkat dua kali lipat dari 5,4 juta pada tahun 1990 menjadi 10,6 juta pada tahun 2014 (WHO, 2016).

Melihat beberapa fakta diatas dapat ditarik kesimpulan bahwa hampir kebanyakan masyarakat indonesia memiliki gaya hidup yang tidak baik. Oleh sebab itu perlu adanya sebuah tindakan yang nyata untuk mengetahui seberapa besar korelasi antara berat badan seseorang terhadap kebugaran kardiofaskuler, khususnya remaja atau mahasiswa untuk menghindari dampak negatif yang terjadi di kehidupan mendatang hal ini 
mengingat gaya hidup mahasiswa saat ini sering nongkrong hingga ber jam jam di warung kopi tanpa adanya gerak yang aktif, sehingga hal tersebut membuat pemicu terjadinya obesitas, oleh karena itu sangat perlu diperhatikan oleh Mahasiswa PGSD Universitas Muhammadiyah Malang yang merupakan jembatan perubahan generasi lebih baik terutama bagi seorang calon guru yang nantinya akan mendapatan sebuah amanah untuk mencerdaskan generasi bangsa, sehingga membutuhkan kebugaran bagi setiap guru yang baik dari pekerjaan lainnya. Oleh karena itu penelitian ini dilaksanakan dengan mengangkat tema "Hubungan Antara Body Mass Index (BMI) Dengan Physical Fitness Pada Mahasiswa PGSD Universitas Muhammadiyah Malang”.

\section{METODE}

Metode yang digunakan pada penelitian ini adalah kuantitatif yang bersifat korelasional, yang bertujuan untuk melihat hubungan antara satu variabel dengan variabel lain. Penelitian ini meliputi rancangan penelitian, deskriptif penentuan subjek penelitian, instrument pengumpulan data, uji validitas, uji reliabilitas dan teknik analisis data yang digunakan untuk menguji hipotesis.

Adapun populasi pada penelitian ini adalah Seluruh mahasiswa PGSD 2017/2018 sejumlah 200 Mahasiswa. Teknik sampling yang digunakan dalam penelitian ini adalah simple random sampling sehingga sampel yang digunakan sejumlah 30 mahasiswa. 15 berjenis kelamin laki-laki dan 15 berjenis kelamin perempuan. Adapun alat ukur tes yang digunakan dalam melakukan penelitian ini menggunakan Speed Test, Muscular Power Test, Strenght Test, Agility Test, Flexibility Test, Endurance Test dan instrumen untuk indek masa tubuh diukur dengan rumus $\mathrm{BMI}=\mathrm{BB}(\mathrm{kg}) / \mathrm{TB}$ kuadrat $(\mathrm{m}) .1$

Tempat penelitian dilaksanakan Universitas Muhammadiyah Malang. Variabel dalam penelitian ini meliputi satu variabel bebas, yaitu Body Mass Index (BMI) (X), serta variabel terikat yaitu Physical Fitness (Y1). Berikut ini adalah skema hubungan variabel x dengan variabel y. Olahan data dilakukan dengan cara dengan menggunakan software SPSS versi 17. untuk mendapatkan hubungan antara indeks massa tubuh dengan tingkat kebugaran jasmani akan menggunakan Uji hipotesis atau analisis bivariat menggunakan uji korelasi spearman.

\section{HASIL DAN PEMBAHASAN}

Dalam melakukan pengukuran hubungan antara body mass index dengan physical fitness perlu dilakukan gambaran umum setiap subjek berdasarkan usia, tinggi badan dan berat badan. Berikut sajian karakteristik umum tersebut dapat dilihat pada tabel 1 berikut.

Tabel 1. Karakteristik umum subjek berdasarkan umur, tinggi badan, berat badan.

\begin{tabular}{ccccc}
\hline \multirow{2}{*}{ Variabel } & \multicolumn{2}{c}{ Laki-laki $(\mathrm{n}=15)$} & \multicolumn{2}{c}{ Perempuan $(\mathrm{n}=15)$} \\
\cline { 2 - 5 } & $\begin{array}{c}\text { Rata- } \\
\text { rata }\end{array}$ & $\mathrm{SD}$ & Rata-rata & $\mathrm{SD}$ \\
\hline Umur & 19,5 & 0,65 & 19,3 & 0,53 \\
\hline Tinggi Badan & 1,69 & 0,06 & 1,54 & 0,05 \\
\hline Berat Badan & 65,10 & 14,10 & 54,50 & 11,38 \\
\hline
\end{tabular}

Berdasarkan tabel 1. adalah jumlah keseluruhan subjek penelitian yaitu 30 mahasiswa yang terdiri dari 15 mahasiswa laki-laki (50\%) serta mahasiswa perempuan berjumlah 15 orang (50\%). Usia subjek 18-22 tahun, dan rata-rata usia laki-laki 19,5 (SD 0,65 ) dan rata-rata usia perempuan 19,3 (SD 0,53). Rata-rata tinggi badan subjek laki-laki 
1,69 (SD 0,06) $\mathrm{m}$ dan rata rata tinggi badan perempuan 1,54 (SD 0,05) $\mathrm{m}$, dan rata-rata berat badan subjek laki-laki 65,10 (SD 14,10) $\mathrm{kg}$, dan rata-rata berat badan subjek perempuan $54,50($ SD 11,38$) \mathrm{kg}$.

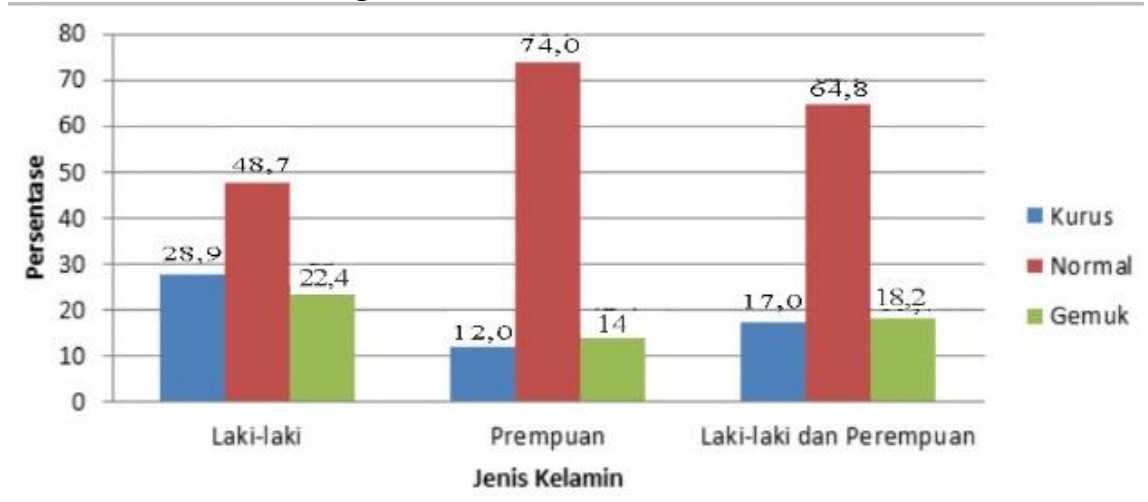

Gambar 1. Distribusi statistic indeks massa tubuh subjek

Gambar 1. Menunjukkan distribusi Indeks Massa Tubuh (IMT) subjek penelitian. Pada subjek laki-laki stelah di lakukan penyesuaian dengan IMT, terdapat sebanyak 5 subjek termasuk dalam kategori kurus (28,9\%), 7 mahasiswa termasuk dalam kategori normal $(48,7 \%)$ dan 3 mahasiswa termasuk dalam kategori gemuk $(22,4 \%)$. Rata-rata subjek mahasiswa laki-laki adalah 22,34 (SD 4,12)kg/m.

Sedangkan untuk IMT subjek mahasiswa perempuan terdapat sebanyak 2 masuk kategori kurus (12\%), berjumlah 10 subjek mahasiswa perempuan masuk kategori normal (74\%) dan 3 termasuk dalam kategori gemuk (14\%). Rata-rata IMT subjek perempuan 22,61 (SD3,99)kh/m. Kesuluran subjek setelah klasifikasi IMT, didapat sebanyak 5 subjek termasuk dalam kategori kurus (17\%), sebanyak 18 subjek mahasiswa termasuk dalam kategori normal $(64,8 \%)$, dan sebanyak 7 subjek mahasiswa termasuk dalam kategori gemuk (18,2\%). Rata-rata subjek IMT secara keseluruhan 22,51 (SD4,02) kg/m.

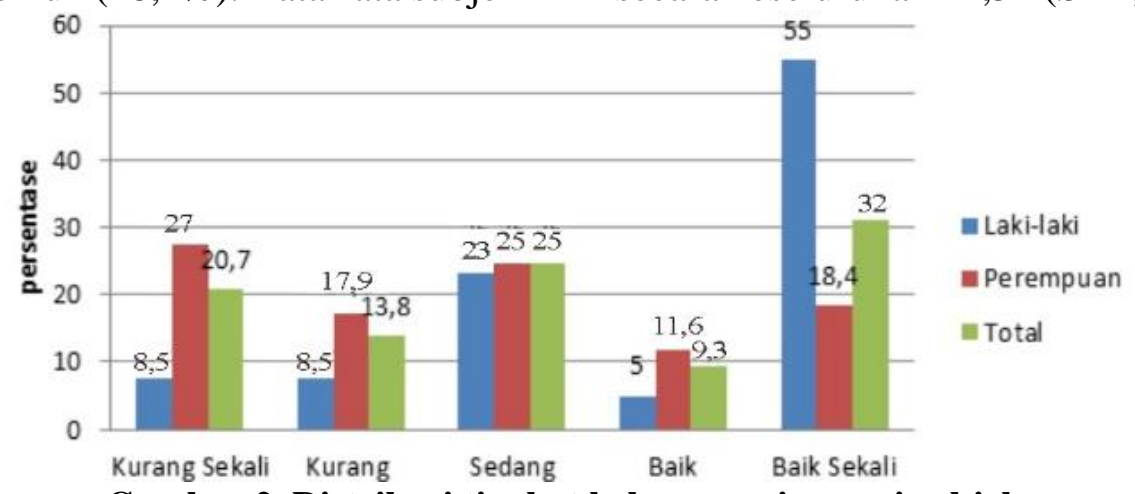

Gambar 2. Distribusi tingkat kebugaran jasmani subjek

Gambar 2. Menunjukkan tingkat kebugaran jasmani subjek penelitian, hasil dari tes kardiofaskuler pada subjek laki-laki terdapat sebanyak 2 subjek termasuk dalam kategori kurang sekali (8,5\%), sebanyak 2 masuk kategori kurang $(8,5 \%)$, sebanyak 4 subjek masuk kategori sedang (23\%), sebanyak 1 subjek masuk kategori baik (5\%), dan sebanyak 6 subjek termasuk dalam kategori baik sekali (55\%). Rata-rata kebugaran jasmani laki-laki 85,53 (SD24,60).

Hasil tes kardiofaskuler pada subjek perempuan setelah dilakukan klasifikasi berdasar pada tingkat kebugaran jasmani, didapat 5 subjek masuk kategori kurang sekali (27\%), sebanyak 3 subjek masuk dalam kategori kurang (17,9\%), sebanyak 3 subjek masuk kategori sedang (23\%), sebanyak 1 subjek masuk kategori baik (11,6\%), dan 
sebanyak 3 subjek masuk kategori baik sekali (18,4\%). Rata-rata kebugaran jasmani perempuan 67,93 (SD21,00).

Hasil tes kardiofaskuler pada subjek keseluruhan setelah dilakukan klasifikasi berdasar pada kebugaran jasmani, didapat sebanyak 6 subjek masuk kategori kurang sekali (20,7\%), sebanyak 4 subjek masuk dalam kategori kurang (13,8\%), sebanyak 8 subjek termasuk dalam kategori sedang (25\%), sebanyak 3 subjek termasuk dalam kategori baik (9,3\%), sebanyak 9 subjek termasuk kategori baik sekali (32\%). Rata-rata kebugaran jasmani secara keseluruhan 74,30 (SD23,65).

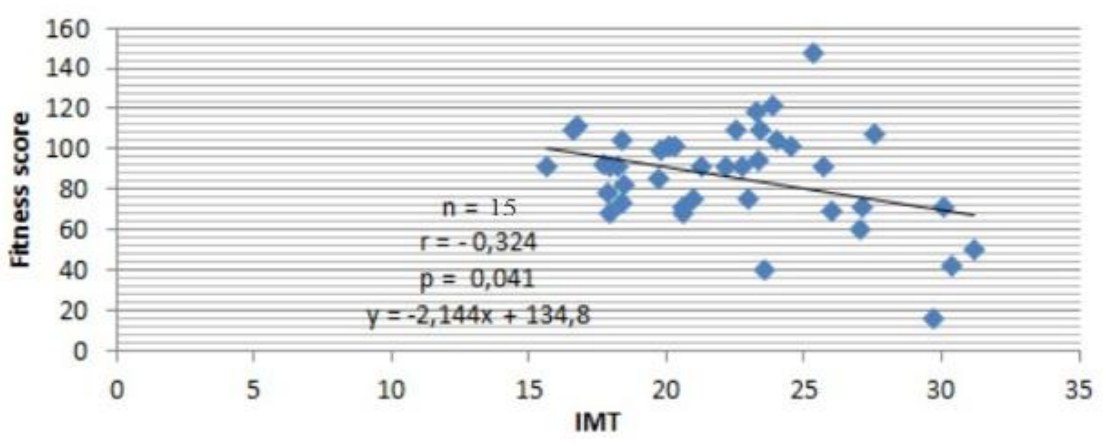

Gambar 3. Korelasi IMT dengan tingkat kebugaran jasmani subjek laki-laki

Gambar 3 diatas yaitu subjek laki-laki memiliki korelasi negative antara indeks masa tubuh dengan tingkat kebugaran jasmani yang menunjukkan semakin tinggi IMT, maka semakin rendah tingkat kebugaran jasmani $p<0,05(P=0,041)$ sangat bermakna interval kepercayaan $95 \%$ dan nilai koefisien korelasi $\mathrm{r}=-0,324$ yang menunjukkan adanya kekuatan korelasi yang lemah.

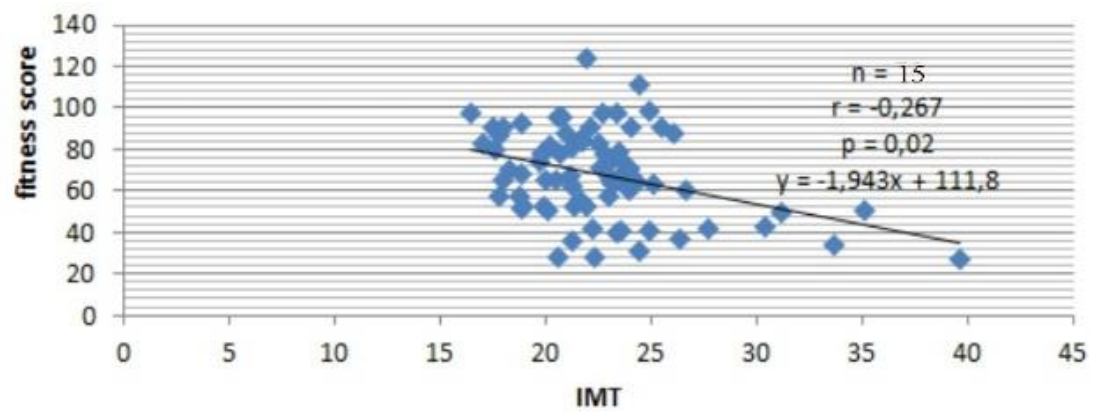

Gambar 4. Korelasi IMT dengan tingkat kebugaran jasmani subjek perempua

Gambar 4 diatas yaitu subjek perempuan memiliki korelasi negatif antara indeks masa tubuh dengan tingkat kebugaran jasmani yang menunjukkan semakin tinggi IMT, maka semakin rendah tingkat kebugaran jasmani $p<0,05(P=0,02)$ sangat bermakna pada interval kepercayaan $95 \%$ dan nilai koefisien korelasi $r=-0,267$ yang menunjukkan adanya kekuatan korelasi yang lemah.

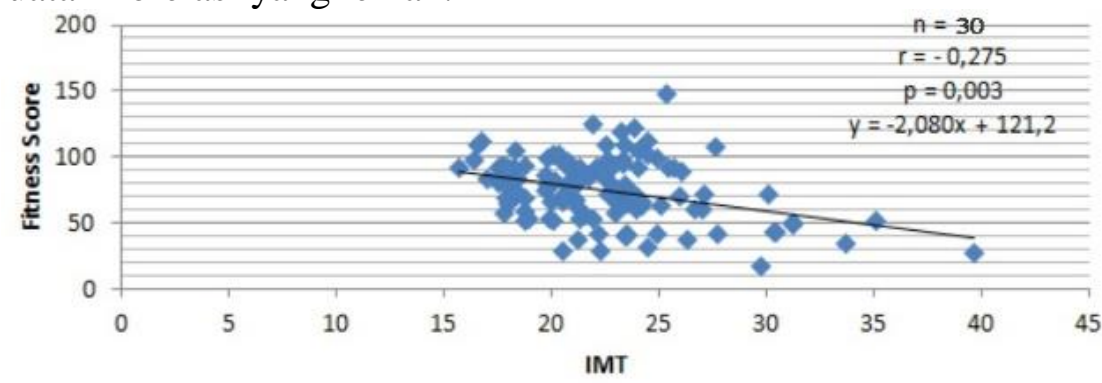

Gambar 5. Korelasi IMT tubuh dengan tingkat kebugaran jasmani subjek laki-laki 
Berdasarkan detail gambar 5 yaitu semua subjek memiliki hubungan korelasi negatif antara IMT dengan tingkat kebugaran jasmani yang menunjukkan semakin tinggi IMT, maka semakin rendah tingkat kebugaran jasmani $p<0,05(P=0,03)$ sangat bermakna pada interval kepercayaan $95 \%$ dan nilai koefisien korelasi $r=-0,275$ yang menunjukkan adanya kekuatan korelasi yang lemah.

Berdasarkan hasil dari pengambilan data dilapangan dan telah diklasifikasikan, dapat diambil sebuah simpulan bahwa subjek laki-laki secara keseluruhan berada pada kategori IMT normal, dengan rata-rata IMT subjek mahasiwa laki-laki 22,34 (SD $4,12) \mathrm{kg} / \mathrm{m}$. subjek mahasiswa perempuan memiliki IMT kategori normal dengan ratarata IMT subjek perempun 22,61 (SD 3,99)kg/m. subjek yng diambel secara keseluruhan juga memiliki kategori yang sama, yaitu berada pada kategori normal, rata-rata IMT secara keseluruhan 22,51 (SD 4,02) kg/m.

Berdasar pada tes dilapangan yang telah dilakukan, terdapat rata-rata kebugaran jasmani laki-laki 85,53 (SD 24,60). Dengan data yang didapatkan tersebut menunjukkan bahwa tingkat kebugaran jasmani subjek laki-laki dalam kategoru baik. Sedangkan yang memiliki persentase paling tinggi $(55 \%)$ berada pada tingkat kebugaran jasmani dalam kategori baik sekali. Subjek mahasiswa perempuan memliki rata-rata tingkat kebugaran jasmani 67,93 (SD 21,00). Hal tersebut menguatkan bahwa level kebugaran tester perempuan berada pada kategori sedang, sedangkan kebugaran jasmani paling tinggi pada kategori kurang sekali dengan persentase $(27 \%)$. Secara keseluruhan subjek rata-rata memiliki kebugaran jasmani 74,30 (SD23,65). Hal tersebut menunjukkan bahwa secara keseluruhan masuk dalam kategori sedang, dan yang memiliki persentase paling tinggi pada tingkat kebugaran secara keseluruhan adalah berada pada kategori baik sekali dengan rata-rata $(32 \%)$.

IMT dengan level kebugaran jasmani sudah pernah dilaksanakan oleh beberapa peneliti. Menurut Joshi P. Bryan C, dan Howat $\mathrm{H}$, terdapat korelasi yang signifikan secara statistic antara kategori IMT dan skor keseluruhan kebuguran $(p=0,05)$. Dengan kata lain, para peserta dengan IMT yang normal lebih mungkin untuk mencapai skor keseluruhan kebugaran mereka yang diklasifikasikan antara IMT kelebihan berat badan (BB) atau overwight, sedangkan menurut Utari terdapat hubungan negative antara IMT dengan tingkat kebugaran jasmani. Subjek mahasiswa laki-laki mendapat angka korelasi sedang $(r=0,666 ; p=0,000)$ sedangkan subjek mahasiswa perempuan angka korelasi lemah ( $r=-$ 0,$442 ; p=0,009$. Menurut Olivia terdapat hubungan negative yang sedang, antara IMT dan kebugaran fisik $(r=-0,521 ; p<0,001)$.

Secara hipotesis pada penelitian ini terbukti adanya korelasi antara IMT dan kebugaran jasmani mahasiswa PGSD Universitas Muhammadiyah Malang. Berdasar pada analisa yang telah dilakukan pada subjek laki-laki, didapat adanya korelasi negative yng lemah antara IMT dengan tingkat kebugaran jasmani. Hal tersebut dapat disimpulkan bahwa adanya hubungan antara jika IMT semakin tinggi maka tingkat kebugaran akan semakin rendah, $p<0,05(p=0,041)$ sangat bermakna interval kepercayaan $95 \%$ dan nilai koefisien korelasi $r=-0,324$.

Pada subjek perempuan juga memiliki hubungan negatif yang lemah antara IMT pada tingkat kebugaran jasmani. Hal tersebut menandakan semakin tinggi IMT semakin rendah tingkat kebugaran jasmani, $p, 0,05(p=0,02)$ sangat bermakna pada interval kepercayaan95\% dan nilai koefisien korelasi $r=-0,267$. Pada subjek secara keseluruhan, didapatkan hubungan korelasi negatif yang lemah antara IMT pada tingkat kebugaran jasmani. Hal tersebut menandakan semakin tinggi IMT, semakin rendah tingkat 
kebugaran jasmani, $p, 0,05(p=0,03)$ sangat bermakna pada interval kepercayaan95\% dan nilai koefisien korelasi $r=-0,275$.

Rangkaian pembahasan di atas menunjukkan bahwa penelitian yang dilakukan sesuai dengan teori yang telah digunakan oleh peniliti, dimana terdapat korelasi yang positif antara IMT dengan kebugaran jasmani, dimana IMT (kegemukan ) akan memeberikan dampak yang signifikan terhadap pergerakan sesorang untuk melakukan aktifitas fisik, hal tersebut dapat ditinjau dari beban persendian akan menopang lebih berat dari badan yang normal, kemudian secara pergekan juga akan terhambat oleh abdomen, dan thoraks juga akan mendapat beban yang berlebih yang akan menghambat proses pernapasan. Dimana proses pernapasan adalah merupakan proses yang penting untuk mendapatkan asup karna jumlah energy diukur dengan banyaknya oksigen yang dikonsumsi otot-otot pernapasan untuk tiap ventilasi. Semakin besar IMT maka akan semakin besar pula beban kerja pernapsan. Beban kerja pernapsan meningkat $60 \%$, obesitas berat sebesar $250 \%$. IMT juga memberikan dampak terhadap (KV) kapasitas Vital, (VCI) volume cadangan inspirasi, (KI) kapasitas inspirasi, (KPV) kapasitas vital paru. Semakin tinggi IMT seseorang maka akan semakin rendah kapasitas paru tersebut sehingga jumlah energy pada obesitas berbanding terbalik dengan jumlah oksigen yang masuk ke dalam tubuh.

\section{SIMPULAN}

Berdasar pada tujuan yang ingin mengetahui hubungan antara IMT dengan kebugaran jasmani mahasiswa PGSD Universitas Muhammadiyah Malang, maka kesimpulannya adalah adanya korelasi yang lemah pada IMT dengan kebugaran jasmani mahasiswa PGSD Universitas Muhammadiyah Malang, baik dari subjek laki-laki maupun dari subjek perempuan dan keseluruhan.

\section{REFERENSI}

Joshi P, Bryan C, Howat H. Relationship of Body Mass Index and Fitness Levels Among School Children. Journal of Strength and Conditioning Research. 2011:1-8

Utari A. Hubungan Indeks Massa Tubuh Dengan Tingkat Kesegaran Jasmani Pada Anak Usia 12-14 Tahun. Semarang: Fakultas Kedokteran Universitas Diponegoro; 2007

Departemen Kesehatan Republik Indonesia Direktorat Jenderal Pembinaan Kesehatan Masyarakat Direktorat Bina Upaya Kesehatan Puskesmas, 2013. Pedoman Pengukuran Kesegaran Jasmani. Jakarta, hlm2-51

Nazzari, H., Isserow, S. H., Heilbron, B., Chb, M. B., McKinney, J., Lithwick, D. J., Morrison, B. N., Nazzari, H., Isserow, S. H., Heilbron, B., \& Krahn, A. D. (2016). The health benefits of physical activity and cardiorespiratory fitness. British Columbia Medical Journal, 58(3), 131- 137.

Atika Maulida Sari, Yanti Ernalia, Eka Bebasari (2017). Hubungan Aktivitas Fisik Dengan Kejadian Obesitas. https://jom.unri.ac.id/index.php/JOMFDOK/article/view/12872

Ogden, Cynthia L; Carroll, Margaret D; Fryar, Cheryl D; Flegal, Katherine M. (2015). Products - Data Briefs. United States: Centers for Disease Control and Prevention. Retrieved Juni 16, 2017, from Centers for Disease Control and Prevention: https://www.cdc.gov/nchs/products/databriefs/db219.htm

WHO. (2016). Obesity and Overweight. Retrieved September 5, 2017, from WHO: http://www.who.int/mediacentre/factsheets/fs311/en/ 